\title{
Social and Cultural Aspect in Foreign Language Motivation defined by Integrative and Instrumental Factors
}

\author{
Valbona Softa ${ }^{1}$
}

\begin{abstract}
This paper aims to investigate the social and cultural aspect in foreign language learning motivation, with main focus English language, as a compulsory course in the official education curricula in Albania, from primary level to Master`s Study Programs. The indicators in this study are the integrative and instrumental variables. Based on the literature review and empirical research data, two research questions are presented in this paper: 1 . At what extent are students motivated to learn English language in terms of integrative and instrumental orientation? 2. Which factor is the best predictor to motivation in English language learning? A quantitative method was approached and data was analyzed through SPSS, 18. Attitude Motivation Test Battery was applied in a sample of 1800 subjects. The reliability Alfa Chronbach coefficient of the Test was (=.88). The findings showed that best predictor variable to motivation in language learning is the integrative factor, at values $\beta=0.476, t=21.110$. Students motivation is also positively varied from the instrumental language orientation, $(\beta=.302, t=16.919$. This result is statistically significant, $\mathrm{p}<0.001$. The study also found that students are moderately motivated to learn the language because of integrative reasons, mean value $(\mathrm{M}=5)$ out of a Likert scale (1-6), $\mathrm{SD}=0.86$; the students are only slightly motivated in terms of language Instrumental orientation, mean value $(\mathrm{M}=4.2)$ out of $(6), \mathrm{SD}=0.1$.
\end{abstract}

Keywords: integrative language orientation, instrumental language orientation, motivation to learn English

\section{Introduction}

English language learning in Albania has long been under the focus of substantial educational reforms, in terms of policy making related to school curricula ${ }^{1}$, application in all levels of study in official education system ${ }^{2}$ and is included as a must take exam in the law for Master Study Program and Doctorate, according to international exams evaluation, (CFER) Common Framework of European References ${ }^{3}$.

The theory of motivation and behavior toward the second language learning process (Gardner RC, Lambert, W., 1958) was born in a context where intelligence and linguistic aptitude were thought to be the only most important variables that stood as predictors of the variance of success in the language learning process. Gardner R.C. (1960), developed his theory at a time when it was still believed that learning foreign languages was a sign of an educated man (Kelly, 1969, cited by Gardner RC, 2005, p.1) and determining success

${ }^{1}$ Document of Strategy for Developement of Preuniversity Education system (2014-2020( Ministry of Education and Sports

2 (Ministry of Education and Sports 2013, Directive No.46 for the Pre university System in the Republic of Albania

3 (MAS), Tiranë, 2015, Amended Law No. 69/2012, and Decision of Council of Ministers, No.78, for State Matura an University Admissions 
in this context was the level of individual intelligence that had historically been measured by the prognosis of foreign languages Henmon, (1929) and Symonds, (1929).

Gardner R.C. (1960) revealed that the motivation factor was related to the success of the students in the language with all the other components involved in the study (skills, attitudes, anxiety, desire to learn foreign language, parental, ethnocentrism etc. .), also found that the student's favorable behavior towards the foreign language community was related to the results of the students in the language (Gardner RC, 1960, p. 52). Gardner (1960) links these attitudes to the integrative motive of students while they study foreign language. Based on this theory, at the center of this study will be the constructions of motivation and attitudes towards foreign language, as with the exposure of Albania to different languages and cultures, it is important to discover how motivated are the students of high schools to learn English, what are their attitudes toward the community that speaks this language and their culture, and how instrumental role of language affects them to learn English language.

Gardner RC, Lambert W. (1972), added two other variables to their research on motivation and attitudes towards foreign language learning, instrumental orientation and the integration orientation of students towards foreign language, explaining that: "Motivation in learning a foreign language is a very broad concept; one learns language for integrative or functional reasons. Integrating motives do not imply being part of the group, but being open to its culture, while the instrumental orientation of the language implies the practical benefits that the individual likes "(Gardner, R.C., 2005, p. 4). These two factors are substantially related to the motivation to learn foreign language, of which the integrative role prevails in the role of function in this relationship (Gardner RC, Lambert, W. (1972). These variables will be considered in this study to detect whether their contribution to the motivation to learn foreign language also applies to the Albanian terrain.

The second main factor in motivating to learn the language is the cultural context (Gardner, 2007), which refers to the social context of the individual and has implications for language learning. It may include implications, such as cultural belief, which is related to foreign language and its study significance, language learning goals, family history background characteristics, peer pressure, etc. Gardner states that "all these traits are expressed in individual attitudes, beliefs, ideals, expectations, etc., in relation to language learning" (Ibid., P. 6).

\section{Literature Review}

\subsubsection{Theoretical definition of socio-cultural variables}

Motivation to learn foreign language The conceptual design of 'Motivation for Foreign Language' is expressed in this study by means of three measuring scales: intensity of motivation to work with language (10 articles), desire for language (10 articles) and attitudes towards learning foreign language 10 articles), (Gardner RC, 2005). The concept of motivation refers to "combining efforts with the desire to achieve the goal of learning foreign language, plus positive attitudes towards language learning. Motivation to learn foreign language refers to the extent to which the individual works or strives to learn the language because of the desire and pleasure it experiences in this activity, "(quoted in Gardner RC, 1985, p.10). In this perspective, Gardner does not 
consider motivation alone as an attempt. He argues that: "The motivated individual makes effort towards the goal, but the individual who simply makes efforts is not necessarily motivated" (ibid). Other factors, which are attributes of the individual, such as perseverance, desire to please the parent, the teacher, the high need for achievement, serve to foster efforts such as social pressure, high demand for a teacher's, compulsory examinations, etc. Gardner cites that "motivation is a complex process and cannot be measured with just one degree" (Gardner R.C., 2005, p. 4).

The second factor best that predicts motivation following education context of language is integrativeness which refers to the cultural and social background of the individual and which has implications to foreign language learning (Gardner, 2007). The conceptual construct Language Integrativeness is related to the desire to draw closer to the community speaking foreign languages, and the positive attitudes towards the culture of this community. This variable is defined by degrees: Integrative Orientation, (4 items), Foreign Language Interests (10 items) and Attitudes to the Foreign Language Community, (10 items), (Gardner R.C., 2005). Social attitudes include attitudes that focus on the cultural aspect of language learning. The integrative role of foreign language is expressed with a sincere and positive interest to people who speak the foreign language and culture that the language represents (Gardner R.C., Lambert W. 1972). In the socioeducational model, the two categories of variables, integrity and attitudes towards the language learning situation are supposed to contribute to the level of motivation of the learner.

Instrumental role of foreign language is related to the desire of students to gain recognition of a social status or material benefits directly from using the language. The instrumental orientation consists of 4 items and refers to language learning for concrete reasons of great benefits, such as career, better education, or high economic perspectives, related to language perfection. If, for example, an individual is motivated to learn foreign language for pragmatic reasons then it is expected that he will be less motivated as soon as he has achieved his goals (Gardner \& MacIntyre, 1991, cited in Gardner, 2005, p.12).

\section{Study Objectives and Research Questions}

This study aims to investigate the students interest in English language learning in terms of their cultural, social or pragmatist orientation towards the language.

The second objective is to measure the impact that integrative and instrumental role of foreign language have in students motivation.

Thus, the two research questions that this paper will analyze are:

1. At what extent are Albanian students oriented to learn English language related to the integrative and instrumental role?

2. What is the impact of socio-educational factors of language integrativeness and instrumentality on motivation to learn the language?

\section{Methodology}

\subsection{Sample of study}

The sample of study was selected according to the national statistics documents 
for students enrolled in Albanian high schools. The selection was performed on the basis of calculation of the representation power in the 'Raosoft sample size Calculator' system. From the sample rating to the $95 \%$ confidence level, $5 \%$ error coefficient acceptance, and response delivery $(50 \%)$, it resulted that the sample size was determined in total $(\mathrm{n}=$ 1800).

\subsection{Instrument}

Attitude Motivation Test Battery (Gardner, R.C., 20044, AMTB), is used as an instrument for measuring the variables and their implications in the research questions. This standardized test comprises 104 items, which are grouped in twelve degrees (Gardner, R.C., 2004). The Socio-Education Model for Learning Foreign Languages (Gardner, 2005) ${ }^{5}$ will be used to analyze only the aggregate socio-cultural aggregates variables, the Integrative Orientation and the Instrumental Orientation of Foreign Language according to the key document for the formation of test degrees ${ }^{6}$.

\subsection{Test Reliability}

The overall reliability of the AMTB instrument resulted in an Alpha Cronbach coefficients. (.88), so it can be said that the test is $88 \%$ consistent or reliable, with 1800 respondents responding to test items. The items are scored according to a Likert scale from 1-6. According to Dörnyei and Taugchi, (2010) these coefficients are acceptable at the level of 0.6 alpha Cronbach and normally suitable for large-scale studies. The scales of integrative orientation, instrumentality and motivation have reached the recommended acceptable reliability level, Alfa Chronbach, $(\geq .7)$.

\subsection{Data gathering and statistical analysis}

This study has a quantitave approach of research and data was gathered in respect to ethics of the study by preserving the respondents ' confidentiality. Following the gathering of data, the Statistical Packet for Social Sciences, SPSS, 18 was used to calculate the results. The statistical analysis in this study included descriptive statistics and frequencies for the first research question, to find the mean value, deviation standard and frequencies of respondents ' answers.

In order to conduct the procedure of Multiple Regression Analysis, the preliminary test Kolmogorov Smirnov was processed in order to meet the conditions of normal distribution of answers related to depedendant variable of motivation, it resulted not significant at $\mathrm{p}>.05$ considering that the statistical significance defined from the start of data procession in this study was evaluated $\mathrm{p}=<.05$. However according to Pallant, 2010, (p.206), the violation of normal distribution condition is not to be taken into consideration due to the great number of sample $\mathrm{N}+30$, which in this study is $\mathrm{N}=1800$.

${ }_{4}^{4}$ Gardner Robert C., (2004), Attitude/Motivation Test battery, International AMTB Research Project http://publish.uwo.ca/ gardner/docs

5 Gardner Robert C., (2005) Integrative motivation and second language acquisition Canadian Association of Applied Linguistics/Canadian Linguistics Association Joint Plenary Talk - May 30, 2005, London, Canada http://publish.uwo.ca/ gardner/docs/caaltalk5final.pdf

6 Attitude/Motivation Test Battery AMTB item-key' document., Questionnaire Keys Master, http://publish.uwo.ca/ gardner/docs/questionaries 
Also, the linearity graphs showed a reasonably acceptable normal distribution of answers for the variable of motivation. Pre analysis included the Pearson Multicorrelation Procedure for the independent variables of integrativeness and instrumentality in order to measure the linear correlation among the variables and it resulted that the variables have a moderate correlation $\mathrm{r}<.07$. This explains accurate prediction of impact that independent variables have on the dependent variable (Tabachnick and Fidell, 2001, f. 84). The correlation coefficient among variables is defined by the indicators presented by Davis $(1971)^{7}$.

After the preliminary analysis was conducted the Standard Multiple Regression Analysis was conducted with the method of simultaneous variable application to measure the impact of integrative and instrumental orientation on motivation to learn the language.

\section{Results}

\subsection{Integrative Language Orientation}

At the national level, according to a Liker scale from 1-6, the mean value for the Language Integrative orientation is $\mathrm{M}=5$ out of 6 . The standard deviation is: $\mathrm{DS}=0.86$. The results showed that high school students $(\mathrm{N}=1800)$ are moderately interested in learning foreign language due to the integrative orientation of English language, see Table 1. At national level, 26.4\% of high school students are very interested in learning foreign language due to their integration role, $28.7 \%$ of them are moderately interested and $23.7 \%$ of students are slightly interested in the integrative role of language. Overall, only $21.2 \%$ of students are unaffected to learn foreign language due to its integrative role and $78.8 \%$ of them are interested in learning the language for integration reasons, see Table 2.

Table 1: Mean value and Standard deviation for Language Integrative Orientation

\begin{tabular}{|l|c|c|c|c|c|}
\hline & $\mathrm{N}$ & Min & Max & Mean value & SD \\
\hline Language Integrative Orientation & 1800 & 1.00 & 6.00 & 5 & 0.863 \\
\hline
\end{tabular}

Table 2: Descriptive statistics frequencies Foreign Language Integrative Orientation

\begin{tabular}{|l|l|c|c|c|c|}
\hline & & Frequencies & Percentages & $\begin{array}{c}\text { Valid } \\
\text { percentages }\end{array}$ & $\begin{array}{c}\text { Cumulative } \\
\text { percentages }\end{array}$ \\
\hline \multirow{5}{*}{ Valid percentages } & Strongly Disagree & 61 & 3.4 & 3.4 & 3.4 \\
\cline { 2 - 6 } & Moderately disagree & 94 & 5.2 & 5.2 & 8.6 \\
\cline { 2 - 6 } & Slightly disagree & 227 & 12.6 & 12.6 & 21.2 \\
\cline { 2 - 6 } & Slightly agree & 426 & 23.7 & 23.7 & 44.9 \\
\cline { 2 - 6 } & Moderately & 516 & 28.7 & 28.7 & 73.6 \\
\cline { 2 - 6 } & Strongly agree & 476 & 26.4 & 26.4 & 100.0 \\
\cline { 2 - 6 } & Total & 1800 & 100.0 & 100.0 & \\
\hline
\end{tabular}

\subsection{Instrumental Language Orientation}

At the national level, according to a Liker scale from 1-6, the mean value for the

7 Meaning of correlation coefficients according to Davis (1971) is: >.70 strong correlation; p.50 - .69 substantial correlations; .30-.49 moderate correlation; .10-.29 weak correlation; .00-.09 insignificant correlation. 
Instrumental Language Motivation is $\mathrm{M}=4,2$. The standard deviation is: $\mathrm{DS}=0.1$. The results showed that high school students $(\mathrm{N}=1800)$ are only slightly interested in learning foreign language due to its instrumental role, (see table 3 ).

Overall, only $21.4 \%$ of the students result to be uninterested to learn English a foreign language due to its instrumental orientation. Out of them, $2.8 \%$ are not interested at all in learning the language for the effect of the instrumental role and $5.8 \%$ are moderately uninterested in terms of language instrumentality.

On national basis, $10.8 \%$ of high school students are strongly interested in learning English as a foreign language because of its instrumental role, $45.2 \%$ of them are moderately interested for the instrumental role of language and $22.6 \%$ of students on national basis are slightly interested for language instrumental orientation (see table 4).

Table 3: Descriptive statistics frequencies Foreign Instrumental Language Orientation

\begin{tabular}{|l|c|c|c|c|c|}
\hline & $\mathrm{N}$ & $\begin{array}{c}\text { Minimum } \\
\text { value }\end{array}$ & $\begin{array}{c}\text { Value } \\
\text { Maximum }\end{array}$ & $\begin{array}{c}\text { Mean } \\
\text { value }\end{array}$ & $\begin{array}{c}\text { Standard } \\
\text { deviation }\end{array}$ \\
\hline Instrumental Language Orientation & 1800 & 1.00 & 6.00 & 4.2 & 0.1 \\
\hline
\end{tabular}

Table 4: Descriptive statistics of frequencies Instrumental Language Orientation

\begin{tabular}{|l|l|c|c|c|c|}
\hline $\begin{array}{l}\text { Instrumental Language } \\
\text { Orientation }\end{array}$ & Frequencies & Percentages & $\begin{array}{c}\text { Valid } \\
\text { percentages }\end{array}$ & $\begin{array}{c}\text { Cumulative } \\
\text { percentages }\end{array}$ \\
\hline \multirow{5}{*}{ Valid } & Strongly disagree & 46 & 2.8 & 2.8 & 2.8 \\
\cline { 2 - 6 } & Moderately disagree & 104 & 5.8 & 5.8 & 8.6 \\
\cline { 2 - 6 } & Slightly disagree & 231 & 12.8 & 12,8 & 21.4 \\
\cline { 2 - 6 } & Slightly agree & 411 & 22.6 & 22.6 & 44.0 \\
\cline { 2 - 6 } & Moderately agree & 813 & 45.2 & 45.2 & 89.2 \\
\cline { 2 - 6 } & Strongly agree & 195 & 10.8 & 10.8 & 100.0 \\
\hline & Total & 1800 & 100.0 & 100.0 & \\
\hline
\end{tabular}

\subsection{Students 'Motivation variances to learn English language predicted by instrumentality and integrativeness factors}

The multiple correlation coefficient $\mathrm{R}=.856$ explains a good level of prediction for the dependent variable motivation; According to Anova a, the value of $R^{2}=.733$ ' stands for the implication of independent variables language instrumentality and integrative that explain $73.3 \%$ of the variances of dependent variable, Motivation to learn a foreign language. The Adjusted $\mathrm{R}$ Square value $\mathrm{R}^{2}$ is $=.57$

Table 5: Model Summary

\begin{tabular}{|c|c|c|c|c|c|}
\hline Model & R & R square & R Square & Adjusted R Square & Durbin-Watson \\
\hline 1 & $.856^{\mathrm{a}}$ & .733 & .732 & .57303 & 1.839 \\
\hline
\end{tabular}

a. Predictive factors: (Constant), Instrumental Language orientation, Language Integrative orientation

b. Dependent Variable: Motivation to learn a foreign language

The F-ratio in the ANOVAb, table 6 (see below) tests whether the overall regression model is a good fit for the data. The table shows that the independent variables instrumental language orientation and integrative language orientation significantly 
statistically predict the dependent variable motivation $F(5,1795)=986.057, p<.0005$ (the regression model is a good fit of the data).

Table 6: ANOVA ${ }^{b}$

\begin{tabular}{|c|c|c|c|c|c|c|}
\hline \multicolumn{2}{|c|}{ Model } & Sum of squares & Degreed of freedom & Mean square & F & Sig. \\
\hline \multirow{3}{*}{1} & Regression & 1618.904 & 5 & 323.781 & 986.057 & $.000^{\mathrm{a}}$ \\
\cline { 2 - 7 } & Residuals & 589.076 & 1795 & .328 & & \\
\cline { 2 - 7 } & Total & 2207.980 & 1800 & & & \\
\hline
\end{tabular}

a. Predictors: (constant Instrumental Language Orientation, Language Integrative orientation

b. Dependent Variable: Motivation to learn a foreign language

The independent variable that best predicts motivation to learn English as a foreign language is integrative orientation of language $\beta=0.476, t=21.110$ and $p<0.001$, and the instrumental role predicts motivation at values $\beta=.302, t=16.919$ and $p=0.001$, (See Table 7). The results are statistically significant and they are confirmed from the Pearson correlation analysis, as well, which revealed substantial correlation among the three variables of motivation, integrative and instrumental role of language $(\mathrm{r}=<.07)$.

Table 7: Statistical significance of the independent variables

\begin{tabular}{|c|c|c|c|c|c|c|c|}
\hline \multirow[t]{2}{*}{ Model } & \multicolumn{2}{|c|}{$\begin{array}{c}\text { Unstandardized } \\
\text { Coefficients }\end{array}$} & \multirow{2}{*}{$\begin{array}{c}\begin{array}{c}\text { Standardized } \\
\text { Coefficients }\end{array} \\
\text { Beta }\end{array}$} & \multirow[t]{2}{*}{$\mathrm{t}$} & \multirow[t]{2}{*}{ Sig. } & \multicolumn{2}{|c|}{ Linearity Statistics } \\
\hline & B & $\begin{array}{l}\text { Standard } \\
\text { Error }\end{array}$ & & & & Tolerance & $\begin{array}{c}\text { Variance } \\
\text { Inflation Factor } \\
\text { (VIF) }\end{array}$ \\
\hline (Constant) & 1.139 & .104 & & 10.980 & .000 & & \\
\hline Integrativeness & .398 & .019 & .476 & 21.110 & .000 & .293 & 3.416 \\
\hline 1 Instrumentality & .062 & .019 & .302 & 16.919 & .000 & .378 & 2.643 \\
\hline
\end{tabular}

a. Dependent variable: motivation to learn English language

\section{Discussions}

The findings in this study do not go in line with other studies in the region. Nikolaou, (2007) found that Greek high school students had high tendencies for both foreign language integrative and instrumentality orientation, meanwhile Albanian students were only slightly interested for the instrumental orientation and moderately interested for the integrative orientation. Also, Greek students were more oriented to the instrumental aspect of language rather than from its integrative aspect which is the contrary for Albanian students in this study. The findings in this study do not go in line with several other studies in the world, Zahra, V. (2008), Iran, Le Huong Hoa (2013), Vietnam, Rehman A. Bilal A. (2014) instrumental of foreign language predominates to the integrative role of foreign language.

The findings in this study though go in line with empirical research by Gardner R.C., et.al. (1972, 1985, 2001, and 2005) who evaluate the integrative role of foreign language in the Socio-Educational Model as the socio-cultural component that prevail the instrumental role of language in relation to foreign language motivation. In the 
integrative orientation they appreciate meeting foreigners who speak English as a native language, being popular with their culture and lifestyles and finding comfort in expressing themselves with foreigners. This is explained with ongoing integrative reforms in Albania, which mark a milestone nowadays for the EU integration progress of the country. On the other hand, Albanian students on national basis tend to be slightly oriented to the instrumental role of language, even though positively affected by its impact on their future, in some respects, such as improving living standards, better pay, job promotion, and career success.

\section{Conclusions}

This paper presented a quantitative research design by conducting statistical analysis, through SPSS 18, in order to examine the variables of integrative language orientation, instrumental language orientation and their impact on motivation to learn English language. It was found that students were moderately oriented to English language learning for integrative reasons expressed through interest in foreign language, attitudes towards foreigners and integrative orientation to the language, mean value of scale $(M=5)$ out of $(6)$. It resulted that Albanian students have a moderate interest to learn English language, have considerable positive attitudes to foreigners, by being open minded to them; they are moderately keen on social and cultural aspect of English language, and the social background of native foreign language speakers. Related to instrumental orientation the students are reported to have a slight interest in English language, $(M=4.2)$ out of (6). Albanian students are only slightly interested to learn the language because of beneficial pragmatist reasons such as a better career, higher income or job promotion. This study also found that Albanian students motivation to learn English language is best predicted by integrativeness orientation, $(\beta=0.476, t=21.110)$. The instrumental role of the language also had significant positive values of impact on their motivation, although the impact was not very strong, $(\beta=.302, t=16.919)$. Thus, this study found that both integrative and instrumental motives have an impact on Albanian students` motivation to learn English language.

\section{References}

Davis, J.A. (1971). Elementary survey analysis Englewood Cliffs, NJ: Prentice Hall.

Gardner Robert C., (2005), Integrative motivation and second language acquisition Canadian Association of Applied Linguistics/Canadian Linguistics Association Joint Plenary Talk - May 30, 2005, London, Canada withdrawn from: http:// publish.uwo.ca/ Gardner/docs/caaltalk5final.pdf

Gardner Robert C., (2009), Gardner and Lambert (1959): Fifty Years and Counting1, CaalOttawa2009talk, p.1. publish.uwo.ca/ gardner/docs/CAALOttawa2009talkc.pdf

Gardner R.C., Masgoret A. M., Tennant J., \& Mihic I., (2004), Integrative motivation: Changes during a yearlong intermediate language course. Language learning, p.54:1, p.1-34 withdrawn from: http://onlinelibrary.wiley.com/doi/10.1111/j.1467- , Language Learning > Vol. 54 Issue 1, 21.05.2014

Gardner, R. C. (1985). Social psychology and second language learning: The role of attitudes and motivation. London: Edward Arnold Publishers, publish.uwo.ca/ gardner/docs/SECONDLANGUAGE1985book.pdf 21.05.2014 
Gardner R. C. (2001), 'Integrative Motivation: Past, Present and Future, Department of Psychology University of Western Ontario, http:// publishes. uwo.ca/ Gardner/docs/ Gardner Public Lecture1

Gardner, R. C. (1958). Social factors in second-language acquisition Unpublished, Master's thesis, McGill University, Montreal, Canada

Gardner, R. C., \& Lambert, W. E. (1972) Attitudes and motivation in second language learning Rowley, MA: Newbury House Publishers

Këshilli i Evropës, (2001), Kuadri i Përbashkët Evropian $i$ Referencave për Gjubët: Të mësuarit, të nxënët, vlerësimi. Strasburg: Këshilli i Evropës. Përkthim nga Haloci A., Delija Sh., Tabaku E., Sula A. (2006), Tiranë: FILARA

MAS, (2015), SZhAPU, Dokumenti i Strategjisë së zhvillimit të arsimit parauniversitar 2014, http:/ /www.arsimi.gov.al /files/userfiles/ apu/karta/ Strategji_ APU_ dokumenti_perfundimtar_24_03_2015.pdf

MAS, (2015), Udhëzim Nr.8, withdrawn on 26.03.2015 për zhvillimin e provimeve të Maturës Shtetërore: http://www.arsimi.gov.al/files/userfiles/matura/2015/Udhezimi i MSH 2015.pdf ,withdrawn on. 05.06 .2015

Nikolaou Alexander (2007), Attitudes and motivation of Greek secondary pupils towards learning English, http:// www. enl. auth. gr /gala/ 14th/ Papers/ English\% 20papers/Nikolaou.pdf

Pallant.J. SPSS Survival Manual, (4th Ed.). (McGraw-Hill Companies. 2010): www.academia.dk/.../Epidemiologi/.../SPSS Survival Manual, 21. 5. 2014

Tabachnick and Fidell (2001), cited in Pallant.J, SPSS Survival Manual, (4th Ed.), (McGraw-Hill Companies. 2010), p.152 